\title{
Memória como disputa política: o caso do assentamento Califórnia-Quixadá
}

Altemar Muniz*

\begin{abstract}
RESUMO
Califórnia foi uma das fazendas mais prósperas do sertão central cearense durante a segunda metade do séc. XIX e primeira metade do século XX. Pertencia a uma das mais tradicionais famílias da região, a Queiroz, de onde nasce a escritora Rachel de Queiroz. Existe uma História oficial da fazenda - respaldada por "historiadores" e memorialistas como José Bonifácio de Sousa, Eusébio Queiroz e Raimundo Girão - baseadas nas memórias de dois membros da família: Esperidião Queiroz de Lima (no livro Antigas Famílias do Sertão) e Rachel de Queiroz (publicados em vários artigos de jornais, revistas cearenses e do sul do país, e no livro Tantos Anos). Esta versão oficial, entretanto, é questionada na memória dos camponeses assentados pelo INCRA em 1986, depois de um conflito que provocou duas mortes. Seus depoimentos trazem reminiscências da época da escravidão, oriundos de uma tradição oral não conhecida por historiadores. O que se percebe nesta divergência de relatos é o confronto de duas visões sobre o mesmo passado, que trazida para a arena política do presente, buscam afirmar o fracasso do modelo agrário pósdesapropriação e, num caso oposto, a reafirmação da justeza e do sucesso da Reforma Agrária.
\end{abstract}

Palavras-chave: Memória e luta política. Conflitos agrários no Nordeste. História. Tempo presente.

\section{Memory as policy dispute: the case of California-Quixadá settlement}

\begin{abstract}
California was one of the most prosperous farms of Central Sertão Cearense during the second half of the century XIX and first half of the 20th century. It belongs to one of the most traditional families of the region, Queiroz, where the writer Rachel de Queiroz would come. There is an Official History of the Treasury - backed by "historians" and memorialists like José Bonifácio de Sousa, Eusébio Queiroz and Raimundo Girão - based on the memories of two members of the family: Esperidião Queiroz de Lima (in the book Antigas Familias do Sertão) and Rachel de Queiroz (published in several articles of newspapers and magazines of Ceara and the south of the country, and in the book Tantos Anos). This official version, however, is questioned in the memory of the peasants settled by INCRA in 1986, after a conflict that caused two deaths. Their testimonies bear reminiscences of the time of slavery, originating from an oral tradition not known by historians. What is perceived in this divergence of accounts is the confrontation of two views on the same past, which brought to the political arena of the present, seek to affirm the failure of the postexpropriation agrarian model and, in an opposite case, the reaffirmation of fairness and success of Agrarian Reform.
\end{abstract}

Keywords: Memory and political struggle. Agrarian conflicts in the Northeast. History. Present time.

\footnotetext{
* É mestre em Sociologia pela Universidade Federal do Ceará e doutor em História Social pela Universidade Federal do Rio de Janeiro. É professor associado da Universidade Estadual do Ceará, no curso de História da Faculdade de Educação, Ciências e Letras do Sertão Central (FECLESC), unidade da UECE em Quixadá-CE. Pesquisa História Política, com ênfase em Tempo Presente, movimento estudantil, imprensa e trajetórias de vida. E-mail: altemarmuniz@gmail.com.
} 
Artigo recebido em 16 fev. 2019

Artigo aprovado em 18 mar. 2019

\section{"Vocês ouviram mentiras, eu posso contar a verdade"}

No segundo semestre de 1999, junto com alunos da disciplina de Introdução aos Estudos Históricos, visitamos o assentamento Califórnia, distante $32 \mathrm{~km}$ do centro de Quixadá, sertão central do Ceará, distante $170 \mathrm{~km}$ de Fortaleza, para entrevistar moradores que participaram da luta pela terra. Tínhamos a intenção de ouvir os depoimentos de moradores e produzirmos um texto sobre a conquista da terra para ser usado nas aulas de história local da comunidade.

No assentamento houve uma conversa preliminar com o presidente da Associação da Califórnia, o jovem Daniel, Dudé (ex-presidente) e Jaime (morador). Na saída do encontro alguns alunos foram abordados por um morador, e que se propunha a dar outra versão sobre a história da Fazenda, pois, segundo ele, a que tínhamos ouvido era "falsa". A sua versão seria a "verdadeira" porque tratava do tempo em que a Fazenda era próspera e não "essa coisa triste de hoje".

Neste momento começamos a perceber que naquele assentamento havia uma disputa em torno da memória da propriedade, que colocava em campos opostos os proprietários, os que mantiveram relações mais estreitas com os antigos donos, e os que lutaram pela sua posse. Além das pessoas, as ruínas da antiga casa principal, a igreja centenária, o cemitério e o açude expunham um passado forte, marcante $e$ interessante. Sinais de um passado que ainda vivia nas posturas políticas de seus moradores, mesmo após 15 anos da desapropriação feita pelo INCRA em 1986.

Além disso, a presença física dos antigos herdeiros, Rachel de Queiroz (prima da escritora) e seu irmão João Tomás, convivendo com seus antigos moradores, mas na condição de vizinhos destes, na parte urbana do assentamento, tornava algo impossível falar dessa história somente a partir do conflito pela terra.

Nossas primeiras pesquisas mostravam em torno do nome Califórnia uma série de informações que beiravam o lendário e o mitológico. Como a fortuna em forma de ouro amoedado e em barras do seu primeiro proprietário, Miguel Queiroz, que costumava enterrá-los na fazenda. Após sua morte, de paradeiro ignorado, muitas escavações foram feitas na terra procurando este tesouro, bem como serviram de inspiração para várias histórias de assombrações de botija. 
Da parte mais "real" e oficial, destacava-se a grande quantidade de escravos, sua condição de primeira fazenda da região a banir a escravidão, a capela dedicada a São Francisco com capelão exclusivo e de uma casa grande com arquitetura em forma de $\mathrm{H}$, com 52 portas e 23 janelas, além de um enorme porão que, segundo versões, servia de senzala para os escravos.

\section{Antigas famílias do sertão}

A parte "oficial" da história da Califórnia se encontra em dois livros: Antigas famílias do sertão, de Esperidião Queiroz de Lima, editado em 1946 no Rio de Janeiro, e Tantos anos, de Rachel de Queiroz e sua irmã Maria Luiza, editado pela Siciliano em 1998, ambos antigos descendentes dos proprietários da Fazenda.

Esperidião Queiroz de Lima era filho de Arcelino Queiroz de Lima, juiz de Direito no Ceará que foi agraciado como herdeiro da Fazenda por seu tio, Miguel Francisco de Queiroz, que morreu em 08 de março de 1882. Miguel não tinha filhos e, dentre os vários sobrinhos que possuía, destinou a Fazenda exclusivamente a Arcelino. Isto gerou problemas judiciais que levaram Esperidião a usar do livro, que tratava da genealogia da família Queiroz, para a defesa da legitimidade da fortuna do pai.

Na parte do livro que trata sobre a Califórnia, Esperidião explicava que ela surgiu em 1855 , quando Miguel Queiroz, dono da Fazenda Junco, que se estendia da ribeira do rio Sitiá, até o rio Choro e a Serra Olho-D'água, numa extensão de 198 km, resolveu aproveitar "o Riacho Grande, que descia da serra do Olho-D'água", e que ao chegar na várzea do rio "passava num apertado entre morros", para a construção de um grande açude "e o estabelecimento de um ótimo sítio (de lavoura) e uma boa fazenda (de criação). As terras fertilíssimas produziam em grande abundância algodão, cana, mandioca e cereais" (Lima, 1946, p. 238).

A Fazenda logo se tornou um povoado e Miguel doou uma parte dela para a Igreja, onde construiu uma capela sob a "proteção de São Francisco de Assis". Essa doação criou um núcleo urbano que foi muito importante na luta pela desapropriação da terra, como explicaremos adiante. A fama da riqueza da Fazenda provocava a inveja até de parentes, como o caso do sobrinho José Severino de Queiroz, que explicaria o surgimento do nome da propriedade. Segundo Esperidião este sobrinho vendo passar em frente de sua propriedade um vaqueiro do tio perguntou:

- Então é verdade que meu tio Miguel descobriu uma outra Califórnia, mais rica do que a da América do Norte, que produz tanto ouro? - Não sei não senhor. Chegando à fazenda, o vaqueiro repetiu o dito de José Severino ao amo, que respondeu divertido: - Pois quando voltar diga a esse senhor meu sobrinho que eu aceito e agradeço a lembrança do nome Calfórnia! Estava mesmo procurando 
um nome bonito para a minha fazenda; pois fica sendo Califórnia! (Lima, 1946, p. 239).

Esperidião retrata os antepassados - como "diligentes, trabalhadores e econômicos", que tiveram a felicidade de juntar uma boa fortuna com a falta de seca entre os anos de 1845 e 1877. Seus escravos "viviam como libertos, maritalmente acasalados e produzindo grandes proles, morando cada família em confortável casa de telha e tijolo, caiada e ladrilhada. Bem nutridos e satisfeitos, trabalhavam com gosto e eram dedicados aos senhores”. Entretanto, o próprio Esperidião abre "brechas" nessa versão quando comenta o pânico que sua bisavó, Dona Maria da Penha, tinha em suas alucinações:

[...] visão terrificante de uma escrava brandindo uma longa faca de ponta, ameaçando matá-la, o que a fazia gritar espavorida, ocultando a cabeça no lençol. A escrava Dominga, vista nessa alucinação moça e bonita, como o fora outrora, era então uma mulata velha, que residia numa fazenda distante e não punha os pés na Califórnia. (Lima, 1946, p. 239).

Sua explicação para tais alucinações, no entanto, era de um "espectro de antigos e ocultos ciúmes do marido, sentidos em segredo e guardados no recôndito de sua alma compassiva $e$ resignada". Entretanto, a versão dos moradores, que não conviveram na Casa Grande, demonstra uma relação nada harmoniosa dos patrões com seus empregados, conforme veremos adiante.

\section{O mito do ouro}

Miguel Queiroz era vendedor de gados. Normalmente levava seu rebanho para vender em Goiania-PE. Segundo Esperidião, Miguel Queiroz só aceitava transacionar com ouro e prata por não pegar em papel-moeda, por considerá-lo "dinheiro sujo", nem em cobre por achar "que azinhavrava" ". Toda transação, venda ou pagamento que fazia era em ouro e prata, sob a forma de moeda jóia e barra. Como a fazenda era auto-suficiente, não se tinha notícia de algum dispêndio feito com esses metais continuamente arrecadados. A forma encontrada para guardar esta fortuna era o "enterramento, em locais disfarçados e sob o maior sigilo", numa "mala de pregaria, feita de cedro, coberta de sola e enfeitada com tachas de metal amarelo, com capacidade avaliada de seis pés cúbicos". O esconderijo só era do conhecimento dos donos e do escravo João Miguel, que "jurava pela salvação de sua alma sigilo absoluto, guardado até a morte" (Lima, 1946, p. 241). 
Esperidião reforça, assim, o mito que até hoje paira sobre Califórnia: a do tesouro escondido de Miguel Queiroz, que será depois abordado pela escritora Rachel de Queiroz e pelos depoimentos recolhidos por nossa pesquisa. O próprio autor falou ainda de escavações de parentes fizeram na Fazenda em busca do tesouro (Lima, 1946, p. 267-269).

\section{Em defesa do pai}

Para além dos mitos, Esperidião buscou fazer uma defesa intransigente de seu pai, Arcelino Queiroz (1837-1895). Para tanto, resgatou a história do tio José, estudante de Direito que morreu de cólera em 1862 e que consternara o pai, Coronel Pedro de Queiroz. Para atenuar a dor do genitor, Arcelino teria deixado seu gosto pela terra e feito os preparatórios para Direito no Liceu do Ceará aos 26 anos de idade. Em Recife, fez o curso de Direito onde se graduou em 14 de novembro de 1871. Casou-se com Rachel Alves de Queiroz Lima, sua prima quinze anos mais nova, no dia 20 de janeiro de 1872. Foi morar com a mulher na sede do Gymnasio Cearense, fundado por ele em Fortaleza no ano de 1871, onde teriam estudado, dentre outros, Rodolpho Theóphilo e Alberto Nepomuceno. Uma epidemia de "beribéri", entretanto, obrigou Arcelino a se refugiar na Serra de Guaramiranga para tratamento, deixando o empreendimento com o sócio Francisco Antônio de Oliveira Praxedes. Em 1873 foi nomeado Juiz Municipal de Canindé e depois Juiz de Direito de Pacatuba. Em 1879 ocorreu o caso que, segundo Esperidião, teria feito seu pai desistir da Magistratura. Arcelino havia decretado a prisão do Presidente da Câmara de Pacatuba por agressão a um adversário político. No almoço oferecido ao presidente da província, José Júlio de Albuquerque, quando da inauguração da Estação de Trem de Acarape, Arcelino teria se recusado a sentar na mesma mesa "ao lado de um réu pronunciado, contra o qual expedi mandado de prisão" (Lima, 1946, p. 239).

Na volta à Pacatuba, soube do pedido do presidente da província de "linha livre" para seu trem, visando impedir a prisão do correligionário. Arcelino se postou à frente do trem, no meio da linha, em sinal de protesto $e$ foi acompanhado por "amigos e admiradores" que colocavam nos dormentes paus de lenha. O trem, obrigado a frear, foi invadido pelo juiz, que arrancou o "indigitado criminoso" do carro presidencial. O Tribunal de Relação, entretanto, desclassificou o crime e concedeu habeas-corpus para o detento. Em protesto, Arcelino pediu demissão ao Presidente da Província e foi morar na Serra da Aratanha. Lá teria recebido o pedido do tio Miguel Queiroz para visitá-lo. Chegou na Califórnia no dia 31 de dezembro de 1879.

Para Esperidião, o próprio Miguel Queiroz pedira a Arcelino que cuidasse da fazenda, de seus negócios e dele mesmo, juntamente com sua esposa, para que tivessem "um resto de vida confortável e tranquila" e evitando que "suas propriedades fossem divididas pelos muitos herdeiros 
e assim ficassem fragmentadas e destruídas". Para tanto, lhe constituiria único herdeiro de seus bens e em troca pedia que viesse morar na Califórnia. Em 1882, três anos depois de nomear Arcelino como único herdeiro, morreu Miguel Queiroz, antes de informar ao sobrinho o lugar onde teria enterrado o ouro. Essa vontade de Miguel Queiroz foi muito contestada pelos descendentes. O próprio Esperidião falou disso quando comentou a visita de sobrinhos, à viúva, que perguntavam sobre o ouro ou "pediam que fizesse outro testamento". Maria da Penha, entretanto, se recusava a contrariar a vontade do marido.

Esperidião também tenta dar ao pai o papel de "libertador" de 82 escravos da fazenda, quando teria assinado suas cartas de alforria, na mesma noite do velório de Miguel Queiroz. Entretanto, no testamento do tio, encontrado no Arquivo Público do Estado do Ceará, já constava a libertação dos cativos após sua morte e de sua esposa. No ano seguinte, 1883, morria Dona Penha, esposa de seu tio.

\section{Ascensão e queda da Família Queiroz}

Arcelino teria ampliado a barragem do açude da Fazenda e garantido uma grande produtividade de peixes, frutas, cereais, algodão, gado, cavalos, jumentos, ovelhas, cabras $e$ porcos. Do canavial saía a matéria-prima para o engenho que produzia rapadura, açúcar e aguardente. Havia ainda fábricas de algodão e farinhas. Entretanto, Esperidião não comentou o processo que o pai respondeu - por desvio de recursos para as secas de 1888 e por superdimensionar o número de trabalhadores em sua fazenda para receber recursos -, movido pelo Instituto de Obras contras as Secas (IOCS) ${ }^{2}$.

Com a proclamação da República, a família Queiroz assumiu a chefia do Governo do Estado do Ceará, com Clarindo de Queiroz, a Chefia de Polícia, com Pedro Thomaz de Queiroz, e uma vaga no Senado Estadual, com o próprio Arcelino Queiroz ${ }^{3}$. Numa das primeiras viagens do novo governador ao interior do estado, quando da inauguração da estação ferroviária do Junco, a seis quilômetros da Fazenda, visitou a Califórnia, acompanhado de esposa, filhas, genro, comitiva de secretários de estado, autoridades, deputados, jornalistas, além de uma banda de música militar, que recebeu os visitantes ao som da Marselhesa e que os acordou ao som da alvorada (Lima, 1946, p. 311). Esta hegemonia política, entretanto, durou apenas dez meses - de 11 de janeiro de 1891 a 17 de fevereiro de 1892. Com a destituição de Deodoro, Clarindo foi derrubado e faleceu no ano de 1893. O Senado Estadual foi dissolvido e Arcelino recolheu-se à 
vida rural, falecendo em 19 de novembro de 1895 (Lima, 1946, p. 316). Sua esposa, Rachel de Queiroz, ficou viúva aos 43 anos, com 10 filhos, sendo oito menores e o último com seis meses de idade. Como estratégia de sobrevivência social, priorizou a educação dos filhos, mandando todos para Fortaleza e posteriormente para o Rio de Janeiro, para realizarem os estudos secundários. Por tal ato, teria sido criticada pelos parentes e amigos que lhe aconselhavam a criar os filhos trabalhando na fazenda, conseguindo, assim, o dinheiro que gastariam nos estudos. Dona Rachel, todavia, dizia que as fazendas divididas em dez partes e sujeitas às secas, "não garantiriam a prosperidade futura dos filhos, que corriam assim o risco de ficarem pobres e ignorantes, como frequentemente acontecia". À replica dos parentes, que argumentavam que gastando tudo com os estudos dos filhos, ficaria pobre e abandonada, retrucava dizendo: "seria bem feito que morresse de fome a mãe tão ruim, que dera ao mundo dez filhos tão egoístas e ingratos" (Lima, 1946, p. 321). Dos seus dez filhos, cinco se formaram. Um dos que não se formou, e que herdou a Califórnia, foi seu filho José Arcelino Queiroz.

Esperidião ainda menciona que sua mãe tinha uma enorme preocupação com o casamento dos filhos. "Tinha horror que eles se casassem mal, numa família que não fosse de costumes irrepreensíveis e 'bem branca' como a sua" (Lima, 1946, p. 323). Era, no entanto, uma "senhora caridosa" que fazia "enormes sacrifícios para nunca faltar ao cumprimento de seu voto de caridade", chegando a ficar sem roupas para vestir os flagelados em farrapos que acorriam às suas terras nas estiagens. Faleceu em 13 de março de 1931, aos 79 anos de idade.

Nas palavras da escritora Rachel de Queiroz, sua avó adoeceu de uma hérnia estrangulada $e$, durante os dez dias em que agonizou, a casa da fazenda era ocupada dia e noite por dezenas de pessoas. "Ficavam ali, a noite toda, sentadas nos degraus. 'Parece um bando de ovelhas', disse alguém. E era verdade" (Queiroz, 1998, p. 254). A escritora via na avó uma pastora, que alimentava e protegia seu "rebanho". Tanto ela como sua irmã, Maria Luiza, evidenciam ao longo do livro expressões idealizadas da família, mas preconceituosas e desqualificadoras dos moradores da Fazenda.

\section{Tantos anos: memórias da segunda geração}

O livro Tantos anos, das irmãs Rachel de Queiroz e Maria Luiza, retrata o lado menos glamouroso da Fazenda. Os trechos mais reveladores pertencem a Maria Luiza. Ela explica a dimensão da Fazenda Junco, de onde nasceu a Califórnia. "Catorze quilômetros à margem da estrada de ferro" e que incluía várias fazendas: Não me Deixes, Itália, Biscaia e a Califórnia. Comenta a crítica que os parentes tinham feito ao seu pai, Daniel de Queiroz, por não ter ficado, na distribuição de bens, com a Califórnia, preferindo a Fazenda Biscaia: "uma extravagância, 
deixar de ser herdeiro da Califórnia, a melhor, a mais rica, a mais bonita fazenda de toda aquela região, para ficar apenas com aquelas terrinhas da beira do rio, que nem casa de morador tinham". Mas Maria Luiza mostrava a postura "correta" do pai pelo fato de a distribuição, em nove partes ideais, ter provocado desacertos entre os herdeiros e, no fim, a Califórnia caíra "na mão de uns primos incapazes e desarvorados, até que acabou sendo desapropriada pelo Incra" (Queiroz; Queiroz, 1998, p. 103-104).

Rachel, a escritora, por sua vez, ao recontar a história de fundação da Fazenda, reclamava da "criminosa indiferença da comunidade" que, depois da desapropriação pelo INCRA, estava deixando vir abaixo a casa-grande, em forma de $\mathrm{H}$, construída pelo avô Arcelino Queiroz (Queiroz; Queiroz, 1998, p. 171). O sentimento de rancor e mágoa com os parentes e os moradores da Fazenda, pela pouca importância à história dos antigos proprietários, pode ser percebido em toda sua integridade na fala de Maria Luiza, quando reclama da condição de caçula que só sabia "o final, a velhice, as sombras do que foi outrora". Como exemplo, citava a Califórnia, que só havia conhecido no período de plena decadência. E sempre que lá ia buscava reviver ou se encaixar nas lembranças dos mais velhos, não se sentia bem-vinda.

Reclamava do tio José Arcelino Queiroz, "viúvo, apático e confuso"; dos primos que, embora crianças, já "mostravam os primeiros sinais da esquizofrenia que depois foi se agravando", pois sempre estavam "dentro de casa, arrastando os chinelos, comendo desbragadamente, com medo de tudo, do sol, de doença, de fruta quente, sem fazer absolutamente nada, nem brincar, nem estudar, nem conversar"; da governanta Firma, "muito boazinha, muito trabalhadora, mas também meio débil mental”; do banheiro grande ao pé do açude com um jorro d'água, mas "cheio de sapos". Tudo "muito melancólico, muito sem graça para uma moça de dezessete anos, minha idade então". Foi se recusando a voltar à Califórnia por não conseguir "recriar coisa nenhuma", por não ser um mundo seu e do qual não tinha nada a descobrir. Seu retorno, contudo, foi traumático. Ela acompanhou o caixão do seu pai, Daniel de Queiroz, que havia falecido em Fortaleza, acreditando "que todo o povo da Califórnia, os caboclos, aquela gente toda com quem ele foi criado, estivessem esperando na beira do rio ${ }^{4}$. Mas não havia ninguém”. Após o enterro, deitou numa rede e começou a chorar pelo pai, "pela frieza daquela chegada, pela desolação que era a Califórnia, pela igreja cheia de morcegos, pelo cemitério esburacado por pebas e chorei por tudo aquilo que me pareceu o corte final de uma etapa da vida" (Queiroz; Queiroz, 1998, p. 173174).

Daniel de Queiroz morreu em 1948. Maria Luiza representava uma geração da família criada no Rio de Janeiro, que ouvia versões de um passado que não conhecia e não entendia, cheia de preconceito com tudo que não fosse urbano. Sua famosa irmã, entretanto, declarava que 
caso morresse na Fazenda Não me deixes, queria ser enterrada no cemitério da Califórnia. Faleceu no Rio de Janeiro, onde foi sepultada em 2003.

\section{Lourdes Lima, a filha da empregada branca}

A versão paradisíaca e oficial sobre a Califórnia tem outras versões na memória dos antigos moradores. Maria de Lurdes Ferreira Lima $^{5}$ conheceu bem a realidade da casa-grande da Califórnia, pois sua mãe viveu sob os cuidados da "madrinha Rachel"6 quando esta enviuvou em 1895. Sua mãe era prendada, sabia fazer bordado, crochê, renda e era de cor "clara". Recebeu o convite para cuidar das crianças, pois, segundo Esperidião Queiroz, sua mãe "Era racista como sua tetravô Francisca de Queiroz, como o eram aliás quase todas as mulheres da família" (Lima, 1946, p. 323).

$\mathrm{Na}$ fala de Lurdes, percebe-se um sentimento de gratidão para com a madrinha Rachel:

E ela ensinou de tudo a mamãe. A mamãe aprendeu crochê. A mamãe fazia renda, estudava, lia muito bem. A madrinha Rachel era muito boa pra ela. Era uma avó pra nós. Uma senhora muito boa mesmo. Mamãe costurava pra ela. Toda costura dela era mamãe que fazia. Quando ela vinha da Serra ela trazia o que ela pudesse trazer pra mamãe e nós. Ela dizia: "Mas madrinha Rachel pra que a senhora faz isso?" "Minha filha porque precisa. Precisa. Você vive aqui trabalhando pra mim, faz tudo pra mim. Cuida da horta. A horta só é bonita porque você cuida. É por isso minha filha" (Lima, 2003d, s/p).

Essa boa relação expandia-se na relação com as filhas e netas da família. "As netas dela chamava a mãe era madrinha. Tudo pra elas era madrinha, madrinha. Quando vinha pra cá, passar férias, aqui podia contar, cedo elas chegava lá em casa pra brincar pela rua mais as outras meninas". Devido a essa proximidade, há uma hesitação em relatar episódios de maus tratos sobre os trabalhadores da fazenda que tenha ouvido ou presenciado: "Não! Eu não me lembro. Eles gostava era... O pessoal eram bom pra eles, num me dizia nada não. Nenhum castigo não. Eles tratava muito bem deles". Entretanto, quando perguntada por Miguel Queiroz, o fundador da fazenda, reproduz o discurso corrente da comunidade sobre suas crueldades.

O velho Miguel Francisco era um velho rico. Ainda nessa semana tava varrendo ali no terreiro e juntando uns tijolos. Eu disse: olha minha filha isso aqui era o tijolo do velho Miguel Francisco. A casa dele ta tudo por aqui. Ele vinha aqui mandava os homem vir aqui. O que enterrava dinheiro, aquele ia morto. Ele mandava matar aquele que enterrava dinheiro (Lima, 2003d, s/p).

Neste trecho, Lurdes endossa o discurso de que Miguel Queiroz enterrava seu ouro com a ajuda de trabalhadores recém-contratados e que viessem de longe, sem familiares, para que, terminado o serviço, fosse executado por seu jagunço e enterrado ao lado do tesouro. 
No que se refere às condições de sobrevivência dos moradores, fala que, para conseguir dinheiro em espécie, visando comprar produtos não produzidos em suas roças, não podia contar com o dono da fazenda: "Tinha que trabalhar era muito, meu filho. Trabalhava na fazenda e por fora. No patrão... Os homem trabalhava, ele num dava não" (Lima, 2003d, s/p).

$\mathrm{Na}$ fala há uma constante comparação entre o que foi a fazenda e no que ela se tornou, tendo como ponto de referência a morte de José Arcelino Queiroz em 1962, tio da escritora e herdeiro da Fazenda, e o casamento de Rachelzinha ${ }^{7}$ em 1971. Do símbolo desta decadência, há um consenso: a destruição da Casa Grande, como se pode constatar na fala de dona Lurdes.

Hoje não tem mais casa não porque a Rachel casou-se com um homem. Este homem não deu conta do recado. Aí foi vendero a fazenda, derrubaro a casa. Era uma coisa linda, a casa da fazenda, de grande e bonita. Bem feita, tinha não sei quantos batentes pra gente subir, chegar lá encima da casa. Bem largo. Era feita num "H", só assim pr'acolá. Uma banda pr'acolá. Agora o sementeiro era grande. Os alpendre grande, bonito e aí vendero, derrubaro tudo. Acabaro com tudo. Hoje lá tem um curral, lá onde era a casa da fazenda. Tudo se acabou-se, assim na fazenda ${ }^{8}$ (Lima, 2003d, s/p).

\section{João Tomás, o herdeiro decadente}

Esse sentimento de fim de uma era "bonita", também se percebe no depoimento de João Tomás Queiroz Lima ${ }^{9}$, irmão de Rachelzinha e herdeiro da fazenda. Ele, entretanto, ressalta sua infância feliz.

Andava a cavalo. Tomava banho no açude. Corria pelos caminhos e ia mais o vaqueiro lá pelo o curral, lá pro cercado das ovelhas. Enfim, passava o dia andando, só entrava em casa na hora da refeição e à tardinha, à noitinha, quando já tava o dia terminando... a gente andava a cavalo. Aquela brincadeira. Ia tomar banho no açude. Se juntava dez, quinze menino ia pro açude e tinha um pau que tinha a numeração dos metros da água, no nível do sangrador. Eles colocaro um pau com a medida de quantos metros. Aí a gente descia pelo pau para apanhar terra no pé do pau. Então a gente só sabia se ele tinha ido até embaixo se ele trouxesse areia. Até me prejudicou, estourei meus dois ouvidos descendo. Era mais de trinta palmos (em torno de dez metros) (Lima, 2003).

Fala da casa grande e de sua grande dimensão para a época, resgatando a ótica de sua mãe, que reclamava do grande trabalho que tinha a mãe dela para administrar o imóvel.

A casa aqui tinha 84 porta e janela. Ela (sua mãe ${ }^{10}$ ) era muito baixinha e dizia: 'Virge Maria!, como é que eu vou... tão pequena vou dar conta de uma casa dessa'. Aí, naquele tempo o meu avô, esse que tem lá no retrato, Arcelino de Queiroz Lima, fez até uma casa... ta certo que era uns dez filho, mas era exagero naquele tempo. Era em forma de "H". Aquele alpendre da frente e atrás tinha outro e o corpo da casa era no meio. Rachel sabia até quantos armadores tinha na casa, eu nunca contei não. Só sei que tinha 84 porta e janela (Lima, 2003). 
Sua fala sobre Rachelzinha expressa o fascínio que a menina parecia ter pela casa. É através de João Tomás que iremos saber algo sobre a irmã mais velha já falecida. Quando se refere ao avô Arcelino, juiz que herdou a terra, e que não conheceu, reproduz a versão oficial da doação da terra por livre vontade do Sr. Miguel Francisco Queiroz:

[...] ele era juiz de Pacatuba aí o Miguel Francisco velho, que era o tio dele... o velho não tinha filho. Aí o velho disse: "Eu vou dar essa fazenda pro meu sobrinho doutor". Naquele tempo não chamava juiz. "Doutor meu sobrinho". Aî os outros sobrinhos dele que viveram aqui no sertão, trabalhando na agricultura aí ficava mal satisfeito com o velho. "Por que o senhor dá o doutor e não dá pra nós? O doutor já tem o emprego dele. O doutor ganha bem e tal. Nós que precisamo da terra do sertão". Aí ele disse: "Não, mas é minha. Eu dou a quem eu quero. Ele é meu afilhado, meu sobrinho. Vou dar pra ele". Aí ele mandou chamá-lo. O portador foi a cavalo da Califórnia pra Pacatuba e o velho, Miguel Francisco, já tava doente. Aí disse: "Você vai a cavalo dizer o doutor Arcelino, lá na Pacatuba, que eu quero falar com ele aqui". Aí ele veio. Ele mandou esperálo na estação. Aí quando ele chegou ele disse: "Eu mandei lhe chamar porque eu vou lhe dar essa fazenda". "Por que meu tio escolheu a mim, pra me dar? O senhor tem tantos sobrinhos?" "Não, mas é minha e eu já disse a eles que dou a quem eu quero. Quem eu quiser e acabou-se a história”. Aí deu (Lima, 2003).

João Tomás reforça a força mítica do fundador Miguel Queiroz até naquele momento em que deu a entrevista, ao se referir a um caso de incorporação espiritual, ou de ataque esquizofrênico de um jovem na Califórnia.

[...] agora pouco tempo ele encarnou no menino lá (na Califórnia). O menino... ficou fora de si e disse que era Seu Miguel. "Isso aqui tudo é meu! Isso aqui tudo é meu!" Aí ele ficava assim, rebolava pedra. Ficava fora de si [...] que ele ainda volta aqui. Ele e o irmão ainda volta aqui. Aí diz que era o velho que se encarnou nele né (Lima, 2003).

Entretanto, negou saber de histórias sobre envolvimento do fundador em assassinatos dos que cavavam os buracos para os baús de ouro que os habitantes contavam. Define o avô Arcelino como um velho divertido, demonstrando uma preocupação em preservar uma memória que justifica posse e legitimidade, mesmo distante no tempo, como ao descrever a alforria dada aos escravos:

Naquele tempo tinha pouca gente. Mas tinha, tinha mais de... naquele tempo tinha pouca gente mas tinha mais de vinte moradores, porque o pessoal dizia que o governo Miguel Francisco era bom. Porque quando ele morreu o meu avô... sim, depois que ele saiu de Pacatuba ele foi ser juiz no Canindé. Aí ele veio pra morte do velho. O meu avô foi quem assinou a carta de alforria dos escravos e todos ficaro morando na Califórnia. Quer dizer, ele não era um patrão ruim, porque todo mundo, teve deles que choraram quando o velho morreu né (Lima, 2003). 
Segundo o testamento de Miguel Queiroz os escravos estavam livres, mas tinham que permanecer servindo sua esposa até a morte, sob pena de perderem a alforria. Portanto, a permanência da fazenda não era bem uma escolha.

Tomás ainda destaca o poder do avô ao mencionar a versão de que ele não permitia a venda de bebidas alcoólicas nas festas do padroeiro, São Francisco, no mês de outubro, demonstrando saudade do tempo em que os donos impunham sua autoridade aos moradores.

Durante a festa, durante a noite do dia três pro dia quatro, também proibia bebida. Naquele tempo o pessoal mandava mais nas suas propriedades, nas suas casas. Hoje parece que ninguém manda em nada, pois é. Ele não queria nem bebida alcoólica e nem jogo de azar, caipira, jogo assim. Não queria de maneira nenhuma (Lima, 2003).

João Tomás morou na Califórnia até 1971, quando sua irmã se casou com um vaqueiro. Rachel tinha então trinta e seis anos e seu esposo era um vaqueiro da fazenda vizinha, a Guanabara, de propriedade de uma tia. A presença ostensiva de seus familiares como moradores, a diferença de oito anos de idade dela para o esposo, o gosto do cunhado pela brincadeira (boêmia), a venda de bens e parte da fazenda que cabia ao casal, além do abandono do lar pelo cunhado (que se concubinou com uma criada da casa) são explicações que João Tomás dá para sua retirada, a venda de sua parte e mesmo para a falência da propriedade.

Então, eles começaro: "Eu vou ficar com esse roçado aqui. Eu vou ficar com aquele ali. Eu vou fazer uma vazante no açude. Eu vou fazer um serviço no sítio". Aí eu desgostando. Eles se aproveitando daquelas terras melhor. Eu vendi minha parte e comprei uma casa aqui (núcleo urbano de Quixadá) e até hoje ainda tou por aqui (Lima, 2003).

Tomás também rende seu réquiem para a época do algodão que, segundo ele, passou a ser cultivado na Califórnia em 1950.

O algodão dava pra tudo viu! A pessoa pagava as contas da bodega. No sertão, de primeiro não tinha mercantil. Aqui era uma viagem por ano, duas. O pessoal se fornecia naquelas bodega mesmo do sertão. Dava pra pagar as bodegas. $\mathrm{O}$ pessoal vestia a família, calçava, comprava o necessário pra casa. No fim ainda tinha que eles chamavam a cata, ainda dava. - "Isso aqui é pro café, pra merenda". O fim da safra né. E era uma coisa que prejudicou todo sertão ou todo o estado, quando o algodão acabou né. Logo é uma coleta muito fácil, muito boa, porque o sujeito planta, vai colher, dá pra vender do roçado mesmo. Dá pra vender pro comercio né (Lima, 2003).

Em sua lembrança, o sistema de parceria na fazenda sempre foi a meia. Entretanto, sabemos que até meados da década de 1950 a relação predominante era de terça. Os motivos que explicam a luta dos proprietários em mudar as relações de trabalho da "terça" para a "meia" se encontram na necessidade de auferirem mais lucros e sustentabilidade econômica em um período de crise econômica. A expansão da pecuária exigia mais terras, além da troca do cultivo 
do algodão arbóreo pelo herbáceo, que significava uma cultura anual, cheia de riscos financeiros. Acrescentava-se, ainda, o medo despertado pelas movimentações camponesas, com o discreto apoio do governo federal, em prol da reforma agrária. Neste contexto, os proprietários de terra promoveram, nos anos de 1955 a 1964, a elevação das rendas, ameaças de expulsão, destruição de plantações e benfeitorias, proibições de novos roçados ou melhorias, perseguições e prisões, além da venda de terra com trabalhadores residindo nelas.

O entrevistado se lembra de problemas com movimentações que denomina de "trabalhistas" numa propriedade da família chamada de Coqueiro, que não consegue precisar bem a data, mas acredita ter sido entre os anos de 1955, 1960, 1961, 1962. Sua fala retrata bem o sentimento de um proprietário rural do período: "Aí começou aquela pregação do povo do Sindicato né. Criação de sindicato e tal e tal. Desde desse tempo começou o homem do campo ficar assim, um pouco rebelde né. Na parte das obrigações na fazenda com o patrão, morador. Começou desde aî" (Lima, 2003).

João Tomás chega a acusar o conflito de terra naquela propriedade como causa da morte do pai: "Até meu pai morreu de trombose nessa época. Ele morreu em 62, na época mesmo que houve a greve que eles não queria dar a parte da fazenda" (Lima, 2003). Para resolver o problema, o entrevistado contou com uma ajuda providencial de um parente juiz.

[...] fui a Fortaleza. Aí tem irmão da minha mãe, que nesse tempo era juiz, José Mário de Queiroz, era professor da Faculdade de Direito. Aí eu falei pra ele. Ele mandou até uma pessoa da polícia aqui, da justiça. Aí ele disse: - "Olha, vocês vão pagar a renda, porque eles também tem conta. Ele tem o negócio dele. Ele vai pagar, vai cumprir e vocês não façam greve não porque, primeiro, vocês são moradores e eles são patrão. Ele é patrão. O pai dele morreu mas ele é o patrão ainda". Aí alguns saíram né. Porque naquela época, geralmente, eles tinham medo das autoridades né. $\mathrm{O}$ que quiser sair... depois com dois anos saiu todo mundo (Lima, 2003).

Esse movimento, abortado no nascedouro da década de 1960, provocou a venda da Fazenda Coqueiro. Em 1979, eles retornaram à Califórnia, gerando um conflito que iria desembocar na morte de um dos cunhados de sua irmã Rachelzinha em 1985, além da morte de um morador. As mortes ajudaram na desapropriação da fazenda, em 1986. O carinho pela propriedade ainda se mostra quando fala de sua relação com o local e seus atuais moradores.

Agora não me lembro da fazenda mesmo. Só me lembro só quando eu vou pra minha barraca, o meu barraco lá. Não me lembro mais nada. O que passou, passou, já passou. E mais! Eu sou bem quisto lá, graças a Deus. Eu ando na casa de todo mundo, dos antigos, de qualquer um que eu chegue lá, naquelas bodegas, qualquer casa que eu chegue lá eu sou bem recebido. Eu, toda época, todo dia, qualquer hora que eu chego lá sou bem recebido. Eu gosto muito dela, eu não tenho ressentimento, eu não tenho nenhuma dificuldade. Naquela época eu era um dos donos também, proprietário, e hoje eu não sou, mas do mesmo jeito que eu andava lá eu ando hoje, com a cabeça erguida, pisando no chão firme e todo mundo lá é meu amigo (Lima, 2003). 


\section{A memória dos trabalhadores do eito}

O contraponto mais exemplar do discurso de João Tomás é de Jaime de Sousa Lima ${ }^{11}$. Sem muita certeza diz que seu pai nasceu no Rio Grande do Norte, trabalhava numa fazenda vizinha chamada Mari e conheceu sua mãe na Califórnia. Tem muita dificuldade de lembrar datas. Sabe, entretanto, precisar a morte de sua mãe: janeiro de 1932. Esta precisão e várias afirmações ao longo da entrevista, sobre sofrimentos inerentes à condição de órfão, evidencia o trauma que o falecimento da genitora causou:

Sofri muito puraí... o senhor sabe: o filho sem mãe aí sofre demais, né? [...] a pessoa pequena na mão de madrasta... na mão de pessoa estranha... praqui, praculá, aí sofre muito, né. Eu acho que um filho sem mãe sofre igual uma mãe. Pobre que não tem mãe no mundo que não sofra, é como um filho também que não tem pai, né? (Lima, 2003c).

Por outras informações, e do próprio depoente, parece que a causa mortis da mãe foi a varíola, que no período da seca de 1932 dizimou muitas vidas, devido às péssimas condições de alojamento, trabalho e alimentação dos trabalhadores que estavam construindo o Açude do Choró, como era o caso do pai de Jaime. Segundo ele, a mãe adoeceu depois de uma ida ao acampamento com o pai. Chega a descrever a cena que presenciou de vários corpos carregados em rede para o cemitério do acampamento. Apesar de várias perguntas sobre os sintomas apresentados pelos doentes, o entrevistado não dava maiores detalhes.

Sr. Jaime teve, do primeiro casamento do pai, quatro irmãs, sendo ele o primogênito. Uma foi para o Pará, outra continua na Califórnia, e Rosita é a única irmã que ele citou pelo nome. Conta que desde menina Rosita não gostava do trabalho da roça e que se "encostou" na casa do Sr. José Arcelino, avô de Tomás, recebendo educação que lhe permitiu tornar-se professora e, mais tarde, secretária da escritora Rachel de Queiroz, com moradas no Rio de Janeiro e em Quixadá. Não cita o nome da mais nova, que foi criada pela tia (que seu pai desposou) e que mora em Fortaleza.

Sem ser perguntado, Sr. Jaime fala dos sofrimentos de negros açoitados por feitores, que tomou conhecimento a partir dos relatos de sua avó, transmitidos por sua mãe. Isto destoa muito da versão humana e paternal dada nos relatos de João Tomás, Rachel de Queiroz e Esperidião Queiroz. 
Quem viu o Baltazar açoitano o outro Baltazar... era dois Baltazar, um preto e um Baltazar branco. Chamava naquela fazenda Baltazar preto e Baltazar branco. Agora o branco é um bichão que só vivia bem engravatado, fardado, todo... E o preto, coitadim, era desses mandados, ia pra bodega... era o pretinho já velhinho, cabeça ruzia como eu tô hoje. Aí quando demorava mais ele descia os degraus... chegava lá, ia encontrar logo com o pobre. Ele não corria não. Ele era doido pra correr, nera, que a pisa ficava maior, né. Aí se acostava perto dele, cobria de rei. Só via as lapadas nas costas, na cabeça. Só via o pobre cobrindo os olhos, a cabeça assim e as lapadas nas costas. Quando o véi cansava, esse Baltazar, véi cansado, aí mandava ele pra dentro. O pobre saía correndo, chorando, né? Não podia correr, já velhinho. Ela me contava muitas coisas passadas da antiguidade. Contou muitas coisa, todos exemplo. Viu açoitar muita gente aqui na Califórnia, nessa casa. A minha vó, os pais dela era escravo. Ela desde de pequenininha, ela contava muito exemplo dos pais dela: o que sofreram de escravo, né (Lima, 2003c).

Noutros momentos do relato, Jaime dá a impressão de que presenciou açoitamentos, o que significa (segundo seu relato) que tal prática manteve-se mesmo em tempos recentes.

Mas eu vi coisa feia, no tempo dessa fazenda. Aí, no tempo dos escravos, que eu não alcancei os escravos. Mas minha avó dizia muito. Mas eu ainda vi uns roteiros. Hoje eu tô com a cabeça branca e eu vi deles pegar desses pobrezinhos escravo e cobrir de rei. Cobrir de rei o pobre só fazia assim: [ele coloca os braços cobrindo o rosto] cobrir a cabeça. "Padim, padim, padim! Não faça isso" e eu vendo essa rumação. Hoje eu ainda conto isso, né (Lima, 2003c).

Como exemplo de outros relatos que a avó lhe fazia, conta o caso do tesouro do Sr. Miguel

Queiroz. Como ele só vendia seu gado em ouro ou prata, costumava enterrar este dinheiro em lugares escondidos da propriedade, escoltado por um escravo de confiança e um capataz que fosse recém-contratado. Depois de enterrado o tesouro o escravo matava o capataz para que o segredo fosse mantido apenas entre ele e o patrão. Acrescenta ainda que parentes do velho chegaram a escavar vários lugares da fazenda atrás desse tesouro. Até a velha casa do Sr. Miguel foi derrubada para tal fim. A escritora Rachel de Queiroz fala disso também em seu livro Tantos anos. Após várias tentativas frustradas, apelaram para uma sessão espírita, onde o escravo baixou, mas se recusou a dizer o lugar do dinheiro, mesmo que isto lhe custasse a salvação da alma.

Lembrou-se de um convite, que recebeu no ano de 1942, de um conhecido de nome Ota Alves, para pegarem uma botija de dinheiro a partir de uma indicação de uma alma.

"Jaime, rapaz se tu tem coragem de arrancar um dinheiro... já duas vez que a alma vem me dar e eu não tenho coragem de arrancar rapaz. Tu quer ir arrancar? É o Miguel Francisco", ele dizendo, né. Aí eu disse: rapaz eu num vou não. Aonde é? - "É lá no Arizona". Nesse tempo era Itália o nome da fazenda, hoje é Arizona. "É lá na Itália, na pedra do bicho, na cabeça de uma grota, no bico de uma pedra. Olha o bujão... fundo e cheio de ouro. Cheio de dinheiro e de tudo quanto é bonito. Tu vai arrancar? Eu mostro o canto a tu". Eu disse: vou não. "Rapaz tu injeita?" Homem quero não. Eu digo: você tomém num injeita? Você que sonha num vai lá e agora quer que eu vá! - "Pois rapaz, eu sei do canto e ela tá insistindo que eu vá arrancar esse dinheiro, mas eu não tenho coragem não. Eu não vou 
não. Agora eu queria que você fosse". Pois eu tomém num vou não! (Lima, 2003c)

Apesar de descendente de escravo e um dos apoiadores da luta pela desapropriação da terra, Jaime faz comentários pouco simpáticos sobre a situação do assentamento. Reclama da ocupação desordenada do espaço urbano que traz pessoas estranhas e cria situações de furtos e insegurança:

Aqui hoje já tá assim, meio revoltado, porque a nação de hoje tá tudo diferente. Hoje é uma nação que se revoltou, assim, gente de fora. Quando era só o pessoal daqui não. Mas quando começou chegar de fora, mudar o lugar, crescer aí. Hoje tá aparecendo muito desmantelo aí. Que às vez peço muito a Deus pra nunca ver certas coisa, porque a gente não aguenta. Tão roubano aí a torto e a direito. $\mathrm{Na}$ semana passada aqui carregaro carneiro que eu criava aqui com as oveinha. Carregaro. Aqui a mulher criava aqui, num sufoco medonho, uma criaçãozinha de galinha, tá tudo preso ali. Carrega... Sumiu quatro peru. Era quatorze peru. O camarada carregou quatro. Bem ali, daquele cajueiro, das mangueiras que têm ali. Umas verdura ali no verão. Os bichos gosta de coisa verde. Ia prali pra comer, quando chegou faltando quatro peru. Se acaba e vão simbora. Não apareceu mais nunca. Por isso, que digo que nosso lugar hoje ta tudo mudado do que era aí rapaz (Lima, 2003c).

Na questão da desapropriação, Jaime sustenta a versão de que foi a escritora Rachel de Queiroz quem ajudou no processo depois da morte do tio José Arcelino.

[...] depois que o patrão morreu, aí acabou-se tudo. Os homem foi, quisero vender a fazenda um homem de Tauá, Antônio Câmara, e outro foi daqui de Quixadá. Chamam Sérgio do Quinzinho. Aí partiro as fazenda e foro vender. Aí a dona Rachelzinha, devido ser criada aqui mais a minha avó... quando foi... o tio dela morreu e ela teve pena do pessoal que era nascido e se criado com ela na rua e tudo. Aí apareceu essa venda desse pessoal, e ela foi, pra não ver eles sofrer na mão de ninguém, aí ela arranjou o mei desse INCRA. Apareceu esse INCRA que hoje tá aí. Aí pra ser desapropriada a fazenda, ela arranjou pra ser desapropriada (Lima, 2003c).

As memórias sobre as relações de trabalho confirmam nossa suspeita de que João Tomás não falou a verdade sobre as mudanças na forma de pagamento da renda, de terça para meia.

[...] no tempo que nós trabaiava aqui a gente trabaiava três dia pra fazenda. O patrão aqui era três dia dele e três dia nosso. Aí o que nós fazia aqui... prantava mandioca, milho, feijão... o que prantasse aqui, algodão, era nosso. Aí, depois ele mudou pra meia. A renda a gente fazia era... a gente trabaiava lá no sítio dele. Fazia o que ele queria: brocava, fazia cerca, trabaiava no engenho dele, dava três dia. Era por conta disso que nós pagava nossos impostos tudo. Era isso né. Aí, depois mudou pra meia (Lima, 2003c).

Jaime lembra que das décadas de 1930 a 1960, tanto para vender a produção de suas roças, como para vender a cachaça e a rapadura fabricada na fazenda, precisavam se deslocar 
para o centro urbano de Quixadá. $\mathrm{Na}$ sua fala, ilustra as dificuldades para realizar tal deslocamento.

Nós saía daqui, nesse tempo, não tinha transporte não. Era difícil inté nós ver um carro. A gente ia de pé. Saía daqui, às vez, de $11,12 \mathrm{~h}$ da noite. Uma ruma de batalhão de gente pra fazer compra em Quixadá. Saía pra poder amanhecer o dia lá. Aí saia $11 \mathrm{~h}$ ou 12 da noite pra amanhecer o dia lá. Não pegava o trem sabe porquê? Porque num dava tempo ninguém fazer os negócio lá, pra comprar, fazer alguma comprinha, pra voltar de trem. Aí só tinha o trem. A gente ia de madrugada, fazia as compra na rua, quando era umas horas do dia o trem vinha, a gente pegava o trem, vinha e soltava ali no Daniel de Queiroz. Dali é uma légua pra cá. A gente vinha de pés, com as coisa. As vez quem levava um jumento num podia levar o jumento no trem, né. Aí botava numa carguinha e vinha tangendo duas ou três pessoas. Botava a carguinha no jumento e vinha. Quando chegava ali no Junco alcançava os outros, já que tinha vindo no jumento na frente. Outras vez a gente ia esperar pelo outro que vinha com as cargas, né. Chegava pela aqui de tardizinha. Nós chegava aqui, era assim. As viagem tudo era de pé. Eu alcancei o tempo que tudo era difícil. Era desse jeito (Lima, 2003c).

Segundo Jaime, o dinheiro arrecadado tinha finalidades de consumo bem simples, já que aos moradores não era permitida a criação de animais.

Comprava uma roupinha, um metro de fazenda, uma roupa pro menino, uma camisa pra vestir e era assim. A gente comprava porque legume a gente fazia pra comer, mas não criava, nós não criava nesse tempo, num tinha uma vaquinha, num tinha um burro, num tinha uma oveia pra vender. Aí a gente comprava uma roupinha, uma chinela que a gente... nesse tempo eu usei muito... Alcancei couro de gado, couro de gado. O camarada fazia duas peça e emendava uma na outra e fazia o cabrestim de correa de sola. Aí fazia os chinelos. Nesse tempo não tinha outro tipo de chinela. Fazia chinela de couro cru. Tinha o tamanco né. Tamanco de pau e fazia essas coisas (Lima, 2003c).

Apesar da fartura de leite em determinadas épocas, que permitia a coleta de cinco litros de leite por família e da grande produção de queijos, os moradores dificilmente comiam tais produtos.

Nós comer era muito difícil. Nós comprava um pedaço de queijo sabe quando é que nós comia um pedaço de queijo? Era na Sexta-feira, na Semana Santa, que a gente trabaiava às vez pra ajeitar um dinheirim pra comprar um quilo de queijo. Pra naquele dia a gente ter um queijinho pra comer. E era desse jeito ai, ele era quem se lucrava de tudo. Nós era só mermo de olhar mermo (Lima, 2003c).

Jaime nos fala sobre a "versão subterrânea" de como o juiz Arcelino Queiroz tornou-se herdeiro de Miguel Queiroz:

Aí o véi foi dando, foi dando, foi cegano... era só o véi e a véia, num tinha um filho. Não tinha conhado, não tinha nada. Aí morava numa casinha que era no tempo de menino. Eu via era bem pertinho da Igreja, bem juntinho da Igreja. Eu não alcancei mais ele, mas ainda alcancei a casa dele ainda. Aí ela dizia que quando o véi tava pra morrer chegou um fulano de tal, um rapaz novo tomando a bença. - 'Meu tio Miguel!" E ele cego disse: "Quem é você?" Ele dizia o nome dele. - "Não, ele não é parente meu não. Que eu não tenho parente nem aderente nesse mundo de jeito nenhum." Aí ele disse: - "Mas tio Miguel, eu sou da famia 
do senhor. O senhor é que não tá se lembrando". Aí começava naquele negócio. Se chegano pra perto né. O véi muito dinheiro e cego né. Já tava cego. Aí foi tomando de conta, foi tomando de conta né, se apoderando. E o pessoal muito tolo, muito medroso, que foi no início que tinha se acabado inté o cativeiro, que já tava no fim (Lima, 2003c).

\section{O inventário que reforça a versão do eito}

Apesar de incorreta, pois de fato Arcelino Queiroz era sobrinho de Miguel Queiroz, essa versão tem elementos reforçados pela pesquisa documental. Miguel Francisco de Queiroz, morreu em 8 de março de 1882. Tinha deixado como herdeira sua mulher Maria da Penha de Queiroz. Seu sobrinho, Arcelino de Queiroz Lima, advogado e ex-juiz de direito, passou a ser o procurador da viúva e posteriormente herdeiro, algo que não ficava claro pelo inventário de Miguel Queiroz, que anteriormente havia ficado responsável pelo inventário de outro parente, Antonio Duarte de Queiroz, e que acabou não o realizando em vida e levou-se a causa para o seu próprio inventário. Após sucessivos adiamentos, devido a resistências da viúva e do sobrinho em assinar as intimações, no dia 11 de dezembro de 1882 foi feito o inventário de Miguel Queiroz, cujo valor total de bens móveis, semimóveis e de raiz totalizavam 4:733\$000 (quatro contos e setecentos e trinta e três mil réis), além de uma dívida a pagar de 2 contos de réis, cujo credor era o próprio Arcelino. Questionado pelo coletor das rendas provinciais, Sr. Francisco Lins Sampaio, a provar a posse do sítio Califórnia, Arcelino se recusou a apresentar os títulos de comprovação por não ser obrigado a isto. No mesmo dia do inventário, Antonio Ricardo da Silveira Bravo, avô e tutor dos filhos de Miguel Francisco de Queiroz Sobrinho (seu genro falecido), exigiu o pagamento da herança de dez (10) novilhas de gado, deixada em testamento pelo Capitão Antonio Duarte de Queiroz e que não haviam sido dadas pelo primeiro inventariante e testamenteiro, Miguel Francisco de Queiroz. Pedia então a execução da dívida, que se estimava em torno de seiscentos mil reis, aproveitando o inventario do espolio. Arcelino alegou que com a morte de Miguel Queiroz $e$ a não mais existência das novilhas deixadas em herança, tornava-se impossível o cumprimento do testamento. O Coletor das Rendas Provinciais, Francisco Lins Sampaio, entretanto, defendeu que a petição fosse cumprida. O juiz, que era terceiro suplente do juiz municipal de órfãos, pediu vistas ao curador geral de órfãos. Como este estava em Fortaleza, foi nomeado João Thomas da Costa para tal função. No seu parecer reforçava a defesa da viúva.

Ante a reivindicação de uma dívida de dois contos de réis, por parte de Arcelino, o coletor das rendas provinciais, questionou a assinatura das testemunhas - todos dependentes do credor e o prazo de vencimento do documento que tinha mais de trinta dias. Assim, o coletor insinuava que a dívida era um golpe contábil para diminuir a perda de bens da tia e, consequentemente, 
seus. Francisco Lins Sampaio acusou a viúva de ter sonegado os bens constantes do traslado de escritura de doação de mortes causa e, portanto, exigia a punição da mesma. Outra cobrança de dívida no valor de $823 \$ 200$ (oitocentos e vinte e três mil e duzentos reis) foi feita por Balthazar Lopes Lima, sobrinho de Miguel Queiroz. Dívida questionada por Arcelino e reafirmada pelo coletor. Após audiência com testemunhas, foi dado ganho da causa a Balthazar Lopes Lima.

Informação interessante é a afirmação do próprio Arcelino de Queiroz que seu tio já estava cego quando da feitura do testamento. O que reforça a versão da tradição oral dos assentados.

Havia uma dívida declarada de dois contos de réis do casal da Califórnia com seu futuro herdeiro. O testamento data de 5 de abril de 1880. Nele consta a libertação dos escravos da fazenda, devendo, entretanto servirem à sua viúva até a sua morte. A alforria livrava a viúva do pagamento de imposto por transmissão de posse. No veredito foi determinado o pagamento das custas processuais, imposto fazendário, dívidas passivas e as destinadas a Balthazar e Arcelino. De um total de 4:733\$000, sobraram para a viúva apenas um conto de réis. A herdeira recorre da decisão para o Tribunal da Reação do Distrito em 1883. Não conseguimos informações sobre a decisão final ${ }^{12}$.

Maria da Penha de Queiroz morreu em 1883. Arcelino faleceu em 19 de novembro de 1895. Sua esposa assumiu a direção da propriedade e a criação dos 10 filhos. Morreu em 13 de maio de 1931. A fazenda passou a ser administrada por José Arcelino Queiroz, o caçula da família. Seus irmãos, entretanto, passaram a gradativamente fundar novas fazendas de suas partes da Califórnia, como foi o caso de Daniel de Queiroz, que fundou a fazenda Arizona e desta cedeu uma parte para a filha Rachel de Queiroz (a escritora) que deu o nome de "Não me deixes".

Em 23 de julho de 1965, Clotilde de Marinho Queiroz vendeu sua parte. Entre 1970 e 1972, os filhos de José Arcelino (João Tomás, Abigail e Rachel) receberam a fazenda como herança. João Tomás, em sociedade com Antônio Tavares e Antônio Câmara, adquiriu partes dela pela compra aos parentes Pedro de Queiroz Lima e Abigail de Queiroz Peroba, em 1972. No dia 13 de março de 1986, foi desapropriada pelo Incra no valor de $\mathrm{CR} \$ 84.064,59$ (oitenta e quatro mil e sessenta e quatro cruzados e cinqüenta e nove centavos $)^{13}$.

\section{José Claudio e a memória pós-desapropriação}


A conquista da terra foi melhor abordada por José Cláudio Garcia ${ }^{14}$, uma das lideranças da Associação de moradores da Fazenda. Em seu depoimento, lembrou do isolamento que as pessoas da Califórnia viviam, pois as vindas ao centro comercial de Quixadá se restringiam a "vender a produção", em "fazer feira no dia de sábado", em "vender um porco ou uma criação" ou, quando "adoecia uma pessoa, vinha uma pessoa pra comprar um remédio". Lembra-se que quando adoeceu de sarampo seu pai foi a pé até Quixadá comprar o medicamento, um percurso de $28 \mathrm{~km}$ em seis horas de caminhada. Recorda que sua primeira ida ao Quixadá teria ocorrido em 1973, então com treze anos, acompanhando a avó, que ia receber a aposentadoria e comprar mantimentos. O transporte, além do trem, era um caminhão Ford, sem banco ou coberta, que fazia a viagem uma vez por semana. Fala que a roupa mais comum, na década de 70 , era camisa "volta ao mundo", calça e bermuda de "omescla" ou de "tergal" com preferência para a "calça boca de sino", feitos a partir de tecidos comprados em Quixadá, principalmente no mês de outubro, por conta das festas de São Francisco. As roupas eram feitas pelas costureiras da comunidade, já que as industriais eram caras demais. Uma das principais costureiras era a Dilsa, bem como sua avó e mãe. A costura era uma atividade secundária, já que não deixavam de trabalhar na plantação.

As festas do padroeiro se iniciavam em 25 de setembro e reuniam familiares, amigos $e$ conhecidos da Califórnia oriundos dos mais diferentes lugares. Do dia 3 para o dia 4 de outubro durava toda a madrugada. Descreve as barracas de palha de carnaúba ou de coqueiro e madeira em forma de "casinha emendada", onde eram vendidos bolos de milho com leite de côco e caldo de rapadura, colocados em tabuleiros feitos de lata de "querozeno" e cobertas com folhas de banananeiras. Eram vendidos ainda refrescos de casca de abacaxi, laranja e refrigerante crush, quente, por falta de eletricidade e geladeira, mas que o "pessoal bebia tão sastifeito"!

A diversão para a criançada eram os carrosséis movidos a braços masculinos, e a iluminação se dava por "tochas de pau" distribuídas ao longo da rua. Recorda ainda dos leilões de "galinha e capote assado", arrematados por agricultores com dinheiro da venda do algodão. Muitas vezes a produtividade era tanta que "ninguém dava vencimento. Botava o gado pra comer. Era uma fartura". Para José Cláudio "as pessoas não tinham nem noção como aplicar dinheiro". Como "não havia assaltantes", o dinheiro era guardado em casa e "ia gastando aos pouquinhos". Não havia uma preocupação em se comprar terreno, gado, animal ou objetos de transporte. Pagavam-se diárias na próxima colheita ou se comprava alimentos como farinha, açúcar e "toicim" nas "bodeguinhas", que vendiam fiado para ser pago na próxima safra do algodão, quase sempre pelo mesmo valor, já que não existia "infração". Entretanto, se plantavam feijão, milho, mandioca e arroz. Criava-se boi, porco, bode e ovelha. 
Seu pai trabalhava "prestando diária" nas plantações de cana da fazenda, através do corte e da moagem da cana. O avô de Cláudio foi gerente da Califórnia na época de Arcelino Queiroz, o avô da escritora. Comenta que seus pais e avós dificilmente falavam sobre as condições de trabalho na fazenda, pois tinham uma parcela de terra cedida pelo dono, onde plantavam mandioca, milho, feijão e algodão, num relação de meia, além de trabalhar três dias nas terras do patrão. As casas eram construídas na terra da Igreja, embora com controle dos donos, que também se impunha sobre os festejos e a segurança da Fazenda.

No dia que ele (Arcelino Queiroz Lima, avô da escritora Rachel de Queiroz) tava com lundu, aí nesse dia tudo era ruim para ele. Dizem que quando o pessoal tava lá na vilinha do Santo, lá, fazendo zuada, ele dava só um grito lá da fazenda o pessoal se calava tudo. Lá não andava polícia, a segurança era ele. As festas, as festividades que havia lá, ele saía da fazenda pra fazer o leilão. Aí ajuntava 2,4 , 5 pessoas, desse pessoal mais antigo, a família de Tungá, família de Garcia e Alípio. Juntava aqueles véis e andava mais ele. Aí pronto. A segurança era ele, todo mundo tinha medo (Garcia, 2002).

Comenta ainda as histórias do pai sobre as secas de 58 e 70, quando foi trabalhar na construção de estradas e compartilhava, com várias pessoas, uma mesma casa próxima da obra. Algumas vezes, mortos por cólera, que seriam enterrados no dia seguinte, jaziam num cômodo, enquanto festas ocorriam em outros espaços da residência. Cláudio começou a trabalhar na Fazenda com dez anos de idade e estudou até a $4^{\mathrm{a}}$ série, sem nunca precisar "ficar de castigo" para fazer as atividades. Nos informa que a fundação da associação dos moradores da Califórnia, se inicia com a venda de parte da fazenda que pertencia a João Tomás a Sergio do Quinzinho, no ano de 1977, para que o comprador, segundo o próprio João Tomás, na versão de Cláudio, "desse um ensino nos negros da Califórnia". Sergio do Quinzinho era filho de importante comerciante da cidade e tinha fama de resolver seus problemas na agressão e no confronto com seus litigantes.

Sérgio do Quinzinho passou a proibir a plantação em área de varzantes e a soltar seu gado no roçado dos moradores. Egidio ${ }^{15}$, futuro sogro de José Cláudio, teria então começado os contatos com o Sindicato dos Trabalhadores Rurais de Quixadá, através do presidente João Ventura e o advogado Ilário Marques (futuro prefeito da cidade pelo Partido dos Trabalhadores nos anos 1993-1996; 2001-2004; 2005-2008; 2016-2020). Os moradores foram orientados, então, a criar uma delegacia sindical para se defender dos atos arbitrários dos novos proprietários, dentre eles o deputado estadual Antônio Câmara. Dentre outros desmandos, proibiram o uso da água do açude para plantação, colocaram gados para comer o roçado plantado dos moradores e tentaram dividir a terra sem pagar indenização das benfeitorias. Fundada a Associação, Cláudio tornou-se secretário e seu sogro, Egídio, o presidente. Uma das primeiras ações da direção foi exigir na justiça indenização pelo prejuízo causado pelo gado dos donos e o pagamento da renda 
conforme o Estatuto da Terra, correspondente a dez por cento da produção, ao invés da metade. O fato de a parte urbana da Fazenda ser "terra de santo" 16 facilitou a reunião dos agricultores com o sindicato, pois não poderiam ser expulsos, ter suas casas invadidas ou derrubadas pelos proprietários. Nessas reuniões nasceu a ideia de desapropriação da Fazenda em prol dos seus moradores.

Um conflito no dia 10 de novembro de 1984 provocou a morte de Francisco Tavares, irmão do esposo de Rachelzinha Queiroz (prima da escritora), pelo morador Manoel Ferreira da Silva. Isso elevou a tensão e como reação dos donos houve a morte do morador José Antônio. Nove meses depois, Califórnia foi desapropriada pelo INCRA e para lá rumaram outras famílias, perfazendo um total de 90. Embora tivessem tido o apoio do Padre Moacir, das Irmãs Cleide e Tereza (padre e irmãs das CEB's), a Associação seguiu as orientações dadas pelo Sindicato dos Trabalhores Rurais de Quixadá e pelo advogado Ilário Marques.

$\mathrm{Na}$ Califórnia os trabalhadores sempre tiveram muito fôlego na coisa. Eles amendrontavam, eles se impunham mais. Por exemplo: no Monte Castelo ${ }^{17}$, eles eram muito dependentes da orientação da Igreja. O sindicato deu todo aquele apoio, lutou, mas a orientação política da luta lá era da Igreja, das Comunidades de Base e do Padre Moacir. Havia conflitos conosco, porque nós tínhamos aqui no sindicato, acho que isso é uma coisa de minha contribuição, uma postura um pouco pragmática das coisas. Conflito é prá se ganhar, não é prá se perder. Se você não ganha, faz acordo. Mas essa história de botar o pessoal prá sofrer e tal, nós nunca tivemos isso no sindicato (Marques,1999, s/p).

Vitoriosa a conquista do solo, segundo Cláudio, uma das primeiras lutas pósdesapropriação foi garantir o caráter comunitário da terra.

Nós queria que a terra lá fosse comunitária, botemos até na Justiça uma vez, porque o chefe do INCRA, na época, já passando o tempo ele parcelou toda fazenda. Queria que entregasse a cada um seu pedaço. Ele dizia: "Vocês não vão possuir terra até quando vocês não possuir seus títulos de terra. Esse negócio comunitário num dá certo pra vocês, porque vai ter uns espertos que vai pegar uma coisa mais de lucro e só vão dizer realmente que vocês são dono de terra quando vocês receber o título na mão de vocês". Nós não aceitamos. Botamos na Justiça, ele parcelou, ganhamos na Justiça pra não parcelar e ainda hoje está comunitário (Garcia, 2002).

Cláudio saiu da Califórnia em 1993, por desentendimentos com a Associação que lhe causaram a expulsão da entidade que ajudou a fundar. Atualmente vive em Quixadá e trabalha no ramo de lanchonetes. Ele faz parte do grupo de pessoas que acreditam que os moradores gastaram o dinheiro dos projetos em coisas distintas da produção agrícola e, por isso, "Você vai lá hoje, se for perguntar de casa em casa... perguntar o que foi que mudou, até agora a pessoa está na mesma, ou na pior, devendo no banco. As coisa que tem lá não dá pra pagar e tá pior, porque não tem nada que... antes não tava devendo a ninguém, hoje tá devendo" (Garcia, 2002). 
Mesma opinião de Alberto Garcia (esposo de dona Lurdes) que viu a decadência da fazenda após a desapropriação, pois as pessoas por não terem mais patrão, não souberam aplicar o dinheiro que receberam do INCRA.

Porque ele deu muito dinheiro e o pessoal não trabaiaro, comero só o dinheiro e pronto. Não fizero nada. O INCRA deu muito dinheiro aqui. Bem dez anos. Pronto. Agora não faz nada, num trabaia. For brincar na rua, gastar dinheiro, pronto. Agora não dá mais. Eles num pagaro e não pagam tão cedo. Com quê? (Lima, 2003b, s/p).

Contra esta visão do presente pós-desapropriação, bem como a reafirmação da boa condição financeira e social atual da Califórnia, invariavelmente vem de lideranças do assentamento. Manoel Ferreira da Silva, vulgo Dudé, ex-presidente da Associação de Trabalhadores Livres da Califórnia no período de 1993 a 1995, usa vários parâmetros de comparação para aferir a qualidade de vida do presente em comparação ao passado:

A gente pegou dois anos de seca, mais não tem parência. Os dois anos de seca que a gente vem pegando, ainda não tem parência na época que a gente trabalhava de meia com a seca. Você pegando duas seca, ainda é melhor, que você fazendo dez saco de algodão, é tudo seu. E antes era do fazendeiro por causa da meia. Nós tinha 90 vaca. Hoje (1999) temos 30. Nós tirava dois litros de leite por família e o resto era prá vender. Eu mesmo tenho quarenta e nove anos. Eu vim vestir uma roupinha assim, isso tá com uns trinta anos prá cá só. Você não vestia uma roupa assim, que nem veste hoje aqui nessa Califórnia (Silva, 1999, s/p).

\section{Memórias sociais, subterrâneas e tácitas}

Esse confronto de visões sobre o presente e o passado da Califórnia se enquadra naquilo que Michael Pollak chama de confronto entre memórias subterrâneas e a memória oficial. A memória subterrânea seria a analise dos excluídos, dos marginalizados e das minorias. De forma silenciosa e quase imperceptível, ela aflora em momentos de crise em sobressaltos bruscos e exacerbados, entrando em conflito e competição com memórias concorrentes. São lembranças confinadas ao silêncio e permanecem vivas ao serem transmitidas de uma geração a outra oralmente, através de redes familiares e de amizades, esperando a hora da verdade e da redistribuição das cartas políticas e ideológicas (Pollak, 1989, p. 3-15). Para o autor, "Se é possível o confronto entre a memória individual e a memória dos outros, isso mostra que a memória e a identidade são valores disputados em conflitos sociais e intergrupais, e particularmente em conflitos que opõem grupos políticos diversos" (Pollak, 1992, p. 204).

$\mathrm{Na}$ abordagem da memória social de Bárbara Mitszal, as resistências populares ao discurso dominante consideram a possibilidade das versões do passado serem emanadas a partir do local 
e do particular, porém, podem ser utilizadas pelos poderes constituídos, numa relação entre a ordem hegemônica e as memórias vernáculas dos grupos sociais. Um modelo dialógico que revela a natureza dinâmica e intersubjetiva da memória social (Mitzal apud Peralta, 2007, p. 8), que parte de um duplo pressuposto: qualquer ato de representação do passado enseja relações de poder; a seletividade da memória é inevitável e inerente, já que interpretamos o passado tendo como base nossa experiência num contexto de quadros culturais de significação mediados por leituras idiossincráticas (p.17).

Durante anos as memórias dos trabalhadores da Califórnia ficaram entre seus habitantes, enquanto a versão oficial ganhava academias e a elite intelectual do Estado. Entretanto, a partir da conquista do poder da cidade pelo Partido dos Trabalhadores no ano de 1993, os relatos dos moradores ganharam relevância em eventos sociais e políticos. O distrito da fazenda, que deixou de se chamar Califórnia desde 1933, voltou a ter esta nomenclatura no ano de 1993 (Costa, 2002, p. 562). Mas o discurso dos que lutaram pela terra, outrora subterrâneo, ou de contra memória, na perspectiva de Foucault, torna-se dominante. Em Foucault, não haveria uma verdade única, universal e hegemônica, pois sempre haveria espaços para resistências e negociações de significados. Haveria uma formação discursiva, produto de trocas de ideias no espaço público de diferentes participantes, gerando um "regime de verdade" (Foucault, 2000, p. 60). A memória dos moradores da Califórnia demarca uma posição sobre a "história oficial" da Fazenda que outros moradores, contrários à desapropriação, ou aos caminhos tomados após a posse, utilizam para defender a visão do fracasso ou de insucesso da nova ordem.

Algo semelhante ao que J. Bodnar chama de processo dinâmico, que envolve debates entre a criação, preservação, erradicação e consensualização de memórias, pois seria inevitável a coexistência de versões conflituais sobre o passado, numa mesma sociedade, que refletem as principais relações de poder que se impõem por sutil processo de comunicação. A pósmodernidade evidencia que os indivíduos pertencem a diferentes grupos e identidades e, portanto, suas memórias são construídas de forma dinâmica, conflitual, seletiva e dialógica, não se limitando a um modelo imposto por um grupo exclusivo (Bodnar apud Oliveira, 1994, p. 295).

Os moradores, principalmente os líderes da comunidade, conhecem o livro de Esperidião Queiroz, mas a maioria não o leu, principalmente por causa do analfabetismo. Entretanto, quando confrontados com as informações da obra, reafirmam a versão oral, mesmo carecendo de fontes para fazê-lo. No contexto da luta pela terra, a versão oral, ou a "memória subterrânea", assumiu a função de legitimadora da posse da terra e contraponto ao discurso saudosista e pessimista sobre o futuro do assentamento.

Entretanto, esta memória oral não saiu do círculo sindical, e dos que lutaram pela terra, para chegar às novas gerações. Numa conferência municipal de Educação, ocorrida em novembro 
de 2013, os professores e alunos da Califórnia, enquanto distrito educacional, apresentaram um projeto de resgate da História do assentamento. Na exposição de fotos e painéis, apenas havia referência aos antigos proprietários, à casa-grande e aos livros de Esperidião Queiroz e Rachel de Queiroz. Ou seja, a escola construída como conquista da luta pela terra apresenta a versão oficial como algo "verdadeiro", relegando os depoimentos e a tradição oral do assentamento. Nossa pretensão inicial, de trabalhar os depoimentos no estudo da história local, está se mostrando mais urgente hoje do que seria há dezessete anos.

\section{Referências}

BODNAR, Jobo. 1992, Remaking America: public memory, commemoration and patriotism in the twentieth century, apud OLIVEIRA, Lucia Lippi. A América hoje: comemorando o quê? Estudos Históricos, Rio de Janeiro, v. 7, n. 14, 1994.

COSTA, João Eudes. Retalhos da História de Quixadá. Fortaleza: ABC, 2002.

FOUCAULT, Michel. Ditos e escritos - arqueologia das ciências e história dos sistemas de pensamento. Rio de Janeiro: Forense Universitária, 2000.

LIMA, Espiridião de Queiroz. Antiga família do sertão. Rio de Janeiro: Livraria AGIR Editora, 1946.

MISZTAL, Bárbara. 2003. Theories of social remembering apud PERALTA, Elsa. Abordagens teóricas ao estudo da memória social: uma resenha crítica. Arquivos da Memória, n. 2, 2007, Centro de Estudos de Etnologia Portuguesa, p. 77.

PERALTA, Elsa. Abordagens teóricas ao estudo da memória social: uma resenha crítica. Arquivos da Memória, n. 2, 2007, Centro de Estudos de Etnologia Portuguesa.

POLLAK, Michael. Memória, esquecimento, silêncio. Estudos Históricos, Rio de Janeiro, vol. 2, n. 3, 1989, p. 315.

POLLAK, Michael. Memória e identidade social. Estudos Históricos, Rio de Janeiro, vol. 5, n. 10, 1992, p. 200212.

QUEIROZ, Rachel de; QUEIROZ, Maria Luiza. Tantos anos. São Paulo: Siciliano, 1998.

\section{Entrevistas}


GARCIA, José Cláudio. Entrevista dada ao autor em 23 de setembro de 2002. Quixadá-CE.

LIMA, João Tomás de Queiroz, entrevista dada ao autor em 20 de fevereiro de 2003, em Quixadá-CE.

LIMA, Alberto Garcia de. Entrevista dada ao autor em 12 de fevereiro de 2003b, Califórnia, Quixadá-CE.

LIMA, Jaime de Sousa. Entrevista dado ao autor em 13 de fevereiro de 2003c, na fazenda Califórnia, QuixadáCE.

LIMA, Maria de Lurdes Ferreira, entrevista dado ao autor em 12 de fevereiro de 2003d, na Fazenda Califórnia, Quixadá-CE.

MARQUES, José Ilário Gonçalves. Entrevista dada ao autor em 11 de novembro de 1999, na cidade de FortalezaCE.

SILVA, Manoel Ferreira da. Entrevista dada ao autor em novembro de 1999, Califórnia, Quixadá-CE.

\footnotetext{
${ }^{1}$ Aquilo que está coberto de azinhavre, a camada esverdeada que se forma em alguns objetos devido a umidade. Cf. https://dicionario.priberam.org/azinhavre, consultado em 02/04/2019.

${ }^{2}$ Localizamos esse processo no Arquivo Público do Estado do Ceará, entretanto, não constava a conclusão do processo.

${ }^{3}$ A família Queiroz participou da Confederação do Equador em 1824 e das Revoltas Liberais de 1842. Por conta disso foram perseguidos seguidas vezes pelas forças do Império.

${ }^{4}$ A entrada da Fazenda Califórnia fica às margens do rio Choró e em determinadas épocas do ano devia ser atravessado em embarcações. Atualmente tem uma passagem molhada no local.

${ }^{5}$ Maria de Lurdes Ferreira Lima e Alberto Garcia de Lima nasceram em 1917 e se casaram em 23 de setembro de 1947. Tiveram sete filhos, sendo apenas um homem. Os pais de Lurdes chamavam-se Manoel Ferreira da Silva e Francisca Ferreira da Silva. Seu pai era originário de Canindé - CE e sua mãe nasceu na Fazenda Califórnia, filha de ex-escrava de nome Matilde, que tinha cinco irmãs e cinco irmãos. A entrevista foi realizada no dia 12 de fevereiro de 2003, em
} sua casa na Fazenda Califórnia. Lurdes faleceu em 2010.

${ }^{6}$ Rachel de Queiroz Lima, avó da escritora.

${ }^{7}$ Rachelzinha se chamava Rachel de Queiroz, filha caçula de José Arcelino Queiroz, herdeiro da Fazenda e tio da escritora. Ela e seu irmão, João Tomás, são as crianças que Maria Luiza Queiroz chamava em Tantos anos de esquizofrênicos. Casou com um vaqueiro de uma fazenda vizinha, a Guanabara, em 1971, e a partir dai a Califórnia passou por vários conflitos que desembocaram na desapropriação de 1986. Rachelzinha morou na Califórnia até o fim de seus dias, em 2002, numa casa emprestada pelo INCRA, já que a antiga casa grande ameaçava desmoronar sobre ela. Passou privações de toda espécie e muitas vezes era auxiliada por doações de seus ex-moradores.

${ }^{8}$ A casa foi derrubada pela comunidade, restando apenas ruínas. Tal fato é explicado pelo dos pais, por medo de que viesse abaixo sobre as crianças, que insistiam em brincar dentro dela. Já estava em situação deplorável pouco depois da desapropriação de 1986.

9 João Tomás Queiroz Lima nasceu em 4 de junho de 1937. Foi um dos últimos herdeiros da fazenda junto de suas irmãs Rachel de Queiroz Lima (1935) e Abigail Queiroz Lima (1940). Filho de José Arcelino de Queiroz Lima, morto em 1962, e Maria Abigail de Queiroz Lima, que morreu em dezembro de 1940. A entrevista ocorreu no dia 20 de fevereiro de 2003, em sua residência em Quixadá-CE. Morreu em 2017.

${ }^{10}$ Sua mãe morreu no parto da irmã mais nova, Rachelzinha, que passou a morar com a avó materna em Beberibe, cidade de onde vinha sua mãe.

${ }^{11}$ Jaime de Sousa Lima nasceu na fazenda Califórnia em 01 de fevereiro de 1924. Filho de Raimunda Ferreira de Souza com Joaquim de Sousa Lima. Bisneto de Escravos. Depoimento dado ao autor no dia 13 de fevereiro de 2003, em sua casa no distrito de Califórnia. Jaime faleceu em 2008.

$121^{\circ}$ Cartório de Quixadá. Processo de Inventario dos bens do Capitão Miguel Francisco de Queiróz, ano de 1882 , pacote: 232, $\mathrm{N}^{\circ}$ do Processo: 21.Arquivo Público do Estado do Ceará.

${ }^{13}$ Transmissão de posse da Fazenda Califórnia. Cartório Enéas, Quixadá-CE, nº de ordem: 11.124, data: 23/07/1965; $\mathrm{n}^{\circ}$ de ordem: 12.221data: 27/02/1970; $\mathrm{n}^{\circ}$ de ordem: 12.222, data: 27/02/1970; $\mathrm{n}^{\circ}$ de ordem: 12.223; $\mathrm{n}^{\circ}$ de ordem: 12.224, data: 27/02/1970; $\mathrm{n}^{\circ}$ de ordem: 12.225, anteriores: 7.281 e 10. 327; 8.135, data:27/02/1970; $\mathrm{n}^{\circ}$ de 
ordem:12.830, data:12/10/1972; $\mathrm{n}^{\circ}$ de ordem: 12.83, data:14/10/1972; $\mathrm{n}^{\circ}$ de ordem: 12.832, anteriores: 12.222 e 12.223, data: $14 ; 10 ; 1972 ; n^{\circ}$ de ordem: 12.832 , matrícula: 2.410 , data: 13/03/1986.

14 José Cláudio Garcia nasceu na Califórnia no ano de 1960. Foi secretário e presidente da Associação de Moradores da Califórnia nos anos de 1980 e 1981.

${ }^{15}$ Egídio Alves de Sousa era oriundo de Caririaçu, região norte do Estado. Chegou na Califórnia na década de 70 e casou-se com uma prima da mãe de Cláudio. Destacava-se por ser muito trabalhador e ajudar até no trabalho veterinário, fazendo partos, aplicando injeções nos bichos e até em pessoas. Foi líder na luta pela terra $e$ presidiu a Associação de Trabalhadores Livres da Califórnia nos anos 1984-86 e 1986-1988. Morreu em 1997 com câncer de próstata (informação dada por GARCIA, 2002).

${ }^{16}$ Terra doada à Igreja por Miguel Queiroz. Os moradores dessa área pagam taxas anuais à Diocese de Quixadá.

${ }^{17}$ Outro conflito de terra em Quixadá, atual Choró, em 1984, que teve muito mais repercussão que a da Califórnia. 